\title{
Współczesne kierunki rehabilitacji w zespołach bólowych kręgosłupa lędźwiowo-krzyżowego - przegląd systematyczny
}

\section{Current trends in the rehabilitation of low back pain - a systematic review}

\author{
Wioletta Łubkowska ${ }^{1 凶}$, Bożena Mroczek $^{2}$ \\ ${ }^{1}$ Uniwersytet Szczeciński, Wydział Kultury Fizycznej i Promocji Zdrowia, ul. Cukrowa 12, 71-004 Szczecin \\ University of Szczecin, Department of Tourism and Recreation \\ ${ }^{2}$ Pomorski Uniwersytet Medyczny w Szczecinie, Zakład Nauk Humanistycznych w Medycynie, ul. Gen. Chłapowskiego 11, 71-204 Szczecin \\ Pomeranian Medical University in Szczecin, Department of Humanities in Medicine \\ \ioletta.lubkowska@usz.edu.pl
}

\begin{abstract}
Introduction: Back pain is considered a lifestyle disease due to its prevalence and the increasingly young age of patients. The aim of this paper is a critical analysis of available guidelines, reports and evidence of diagnostic and therapeutic procedures in low back pain. This paper presents epidemiology, aetiology, diagnosis and selected methods of treatment and prevention of low back pain.

Materials and methods: The literature was reviewed based on the Polish Medical Bibliography computer database and the English-language PubMed, Web of Sciences and Cochrane Library database. Additionally, the Google Scholar search engine was used. The presented works have been analyzed in terms of their scientific reference and compliance with the principles of Evidence-Based Medicine. In order to obtain high-quality recommendations, the review included current scientific evidence based
\end{abstract}

on peer-reviewed scientific publications, systematic reviews, meta-analyses and randomized controlled trials.

Results: According to numerous studies, bed rest is ineffective and should not be recommended. The literature on the effects of acupuncture, TENS, cold therapy and traction on low back pain is too heterogeneous; further high-quality research is needed before any final conclusions are drawn. Strongly recommended methods for treating low back pain symptoms are: physical exercise, manual therapy, and education.

Conclusions: Further research is required to identify effective non-pharmacological treatments for low back pain, and to understand the additional benefits of combining individual interventions, as well as which treatment combinations and sequences are most effective.

Keywords: low back pain; back pain syndromes; M54 ICD-10; diagnosis; epidemiology; treatment; rules of conduct.

\begin{abstract}
ABSTRAKT
Wstęp: Zespoły bólowe kręgosłupa lędźwiowo-krzyżowego ze względu na powszechność zjawiska oraz coraz młodszy wiek pacjentów uznaje się za schorzenie cywilizacyjne.

Celem artykułu była krytyczna analiza dostępnych wytycznych, raportów i dowodów dostarczających argumentów dotyczących postępowania diagnostyczno-terapeutycznego w bólach krzyża. W pracy przedstawiono epidemiologię, etiologię, diagnozę oraz wybrane metody leczenia i profilaktyki bólu krzyża.

Materiały i metody: Dokonano przeglądu danych literaturowych w oparciu o bazę komputerową Polska Bibliografia Lekarska oraz anglojęzyczną bazę danych PubMed i Cochrane Library. Dodatkowo wykorzystano wyszukiwarkę Google Scholar. Prezentowane prace przeanalizowano pod względem ich referencyjności naukowej i zgodności z zasadami Evidence-Based Medicine. W celu uzyskania rekomendacji na najwyższym poziomie w przeglądzie zostały uwzględnione aktualne dowody naukowe oparte na recenzowanych publikacjach naukowych, przeglądach
\end{abstract}

systematycznych, metaanalizach i przeprowadzonych randomizowanych badaniach kontrolnych.

Wyniki: Według licznych badań leżenie w łóżku jest nieskuteczne i nie powinno być zalecane. Literatura w odniesieniu do wpływu akupunktury, TENS, terapii zimnem i trakcji (wyciąg) na leczenie bólu krzyża jest zbyt niejednorodna i potrzebne są dalsze wysokiej jakości badania, zanim jakikolwiek końcowy wniosek zostanie postawiony. Mocno rekomendowane w leczeniu objawów bólu krzyża są: ćwiczenia fizyczne, terapia manualna oraz edukacja.

Wnioski: Konieczne są dalsze badania w celu zidentyfikowania skutecznych niefarmakologicznych metod leczenia bólu krzyża oraz zrozumienia dodatkowych korzyści wynikających z łączenia poszczególnych interwencji, a także tego, które kombinacje leczenia i sekwencje są najbardziej skuteczne.

Słowa kluczowe: bóle krzyża; zespoły bólowe dolnego odcinka kręgosłupa; M54 ICD-10; diagnostyka; epidemiologia; leczenie; zasady postępowania.

\section{WSTĘP}

Zespoły bólowe kręgosłupa są objawem choroby, która może umiejscawiać się w różnych tkankach i narządach, również odległych od kręgosłupa. W Międzynarodowej Statystycznej
Klasyfikacji Chorób i Problemów Zdrowotnych Światowej Organizacji Zdrowia [1] (International Statistical Classification of Diseases and Related Health Problems World Health Organization) znajduje się kilkadziesiąt problemów zdrowotnych mogących prowadzić do dolegliwości bólowych pleców. 
Są to m.in.: zmiany zwyrodnieniowe kręgosłupa (M47), inne choroby kręgosłupa (M48), choroby krążków międzykręgowych lędźwiowych i innych z uszkodzeniem korzeni nerwów rdzeniowych (M51.1), inne określone przemieszczenia krążków międzykręgowych (M51.2), niestabilność kręgosłupa (M53.2), choroby korzeni nerwów rdzeniowych - zespoły korzonkowe (M54.1), rwa kulszowa z bólem lędźwiowo-krzyżowym (M54.4), ból okolicy lędźwiowo-krzyżowej (M54.5), inne bóle grzbietu (M54.8), nieokreślone bóle grzbietu, bóle pleców BNO (M54.9), dysfunkcja segmentarna i somatyczna (M99.0), inne określone zaburzenia ośrodkowego układu nerwowego (G96.8) czy też uporczywe psychogenne bóle grzbietu (F45.4) [1]. Jest to w istocie kilka jednostek chorobowych, dla których wspólnym objawem osiowym jest ból jednego lub kilku odcinków kręgosłupa. Orzecznictwo w zespołach bólowych kręgosłupa jest trudnym zagadnieniem. Chorzy z zespołami bólowymi kręgosłupa są leczeni przez lekarzy rodzinnych oraz lekarzy różnych specjalności, np.: ortopedii, reumatologii, neurochirurgii, a także rehabilitantów, fizjoterapeutów, osteopatów. Tak duże rozproszenie choroby stanowi problem interdyscyplinarny, a wysoka zachorowalność świadczy o jego powadze z punktu widzenia socjoekonomicznego.

Zespoły bólowe kręgosłupa są jedną z najczęściej rozpoznawanych chorób układu kostno-stawowego [2], najczęstszą zgłaszaną dolegliwością w badaniach populacyjnych [3] oraz drugą główną przyczyną absencji chorobowej [4]. Ponadto są one najczęstszą przyczyną niezdolności do wykonywania pracy zawodowej [5], stanowiąc jeden z głównych powodów niesprawności fizycznej osób poniżej 45. r.ż. [6, 7]. Dolegliwości najczęściej dotyczą kręgosłupa lędźwiowego (80\%), kręgosłupa szyjnego (18\%), najrzadziej kręgosłupa piersiowego (2\%) [8]. Zespoły bólowe dolnego odcinka kręgosłupa, tzw. bóle krzyża, jako określenie wywodzące się z terminologii angielskiej (low back pain), odnoszą się do skomplikowanego szeregu dolegliwości umiejscowionych głównie w okolicy lędźwiowej, lędźwiowo-krzyżowej i krzyżowo-biodrowej, czasem promieniujących do kończyn dolnych. Ze względu na charakter dolegliwości podzielono je na: ból ostry - 6 tygodni lub mniej, ból podostry - 7-12 tygodni i ból przewlekły - więcej niż 12 tygodni objawów [9].

Powszechność występowania tego schorzenia [2] powoduje znaczne obciążenie dla budżetu państwa, obejmujące koszty bezpośrednie związane $\mathrm{z}$ diagnostyką, leczeniem i rehabilitacją oraz koszty pośrednie, jak: renty, zasiłki, absencje chorobowe $[10,11,12]$. Dagenais i wsp. dokonali przeglądu literatury w celu zidentyfikowania kosztów związanych z leczeniem bólu krzyża ponoszonych w Stanach Zjednoczonych oraz krajach takich jak: Australia, Belgia, Japonia, Korea, Holandia, Szwecja, Wielka Brytania. Największy odsetek bezpośrednich kosztów medycznych dla bólu krzyża stanowiły: fizykoterapia (17\%), opieka szpitalna (17\%), leczenie farmakologiczne (13\%), podstawowa opieka zdrowotna (13\%), opieka ambulatoryjna (8\%) oraz diagnostyka obrazowa (7\%) [11]. Dla przykładu w Stanach Zjednoczonych całkowite koszty związane z leczeniem bólu krzyża przekraczają 100 mld USD rocznie [10] i są drugą najczęstszą przyczyną niepełnosprawności, dotykając ok. 7,6 mln osób [6].
Wysoka zachorowalność, nawrotowość i mała skuteczność terapeutyczna bólów krzyża, jak również koszty, które niesie za sobą ta dolegliwość, skłaniają do szukania efektywnych i powodujących jak najmniej działań niepożądanych metod leczenia oraz upowszechnienia zasad i działań profilaktycznych tego schorzenia. Prezentowane do tej pory w naszym kraju ogólne zasady postępowania diagnostyczno-leczniczego wymagają okresowego uaktualnienia w celu zapewnienia skuteczności terapii oraz kontroli kosztów. Jak pokazują badania retrospektywne prowadzone na grupie 300 osób [13], gdzie poddano analizie treściowej losowo wybrane karty pacjentów cierpiących na zespoły bólowe kręgosłupa, proponowane terapie nie zawsze były zgodne z modelem rehabilitacyjnym leczenia ostrego i przewlekłego bólu przedstawionym w klinicznych wytycznych Institute for Clinical Systems Improvement (ICSI) [9], National Institute for Health and Care Excellence (NICE) [14], jak i wytycznych autorstwa Amerykańskiego Kolegium Lekarzy (American College of Physicians - ACP) oraz Amerykańskiego Towarzystwa Bólu (American Pain Society APS) [15].

Celem pracy była krytyczna analiza dostępnych wytycznych, raportów i dowodów dostarczających argumentów dotyczących postępowania diagnostyczno-terapeutycznego w przypadku bólów krzyża. Celem dodatkowym było przedstawienie epidemiologii, etiologii, diagnozy oraz wybranych metod leczenia i profilaktyki w bólach krzyża. Intencją autorów było zwrócenie uwagi na potrzebę wprowadzenia zmian w istniejącym modelu leczenia bólu krzyża w Polsce.

\section{METODA}

Dokonano krytycznego przeglądu piśmiennictwa naukowego opublikowanego od 1 stycznia 2000 r. do październikiem 2017 r., w oparciu o bazę komputerową Polska Bibliografia Lekarska i anglojęzyczną bazę danych PubMed i Cochrane Library. Dodatkowo wykorzystano wyszukiwarkę Google Scholar. Użyto wielu kombinacji pokrewnych słów kluczowych, jak: bóle krzyża, bóle kręgosłupa lędźwiowego, zespoły bólowe dolnego odcinka kręgosłupa, bóle pleców, bóle grzbietu, ból okolicy lędźwiowo-krzyżowej, rwa kulszowa, przewlekły ból kręgosłupa, diagnostyka, etiologia, leczenie, rehabilitacja, rekomendacje, wytyczne, zasady postępowania, M54 wg ICD-10.

Wybrano wytyczne i artykuły przedstawiające dostępne dowody opublikowane w języku polskim lub angielskim w recenzowanych czasopismach, które musiały być zgodne z zasadami badań naukowych i mogły zostać wykorzystane jako podstawa dla zaleceń sformułowanych zgodnie z wytycznymi Evidence-Based Medicine (EBM). Do oceny wiarygodności naukowej prezentowanych prac badawczych posłużyły następujące stopnie rekomendacji: A - spójne badania pierwszego poziomu, B - stałe badania 2. lub 3. poziomu albo ekstrapolacje (ekstrapolacje dotyczą sytuacji, w których dane są wykorzystywane w sytuacji potencjalnie różniącej się klinicznie od pierwotnej sytuacji badawczej [16]) z badań 1. poziomu, C - badania 4. poziomu albo ekstrapolacje z badań 2 . lub 3. 
poziomu, D - dowód na 5. poziomie lub niepokojące niespójne lub niejednoznaczne badania na żadnym poziomie [16]. W celu uzyskania rekomendacji na najwyższym poziomie w przeglądzie zostały uwzględnione tylko dowody wysokiej jakości referencyjności naukowej, lokujące się w 1.-3. poziomie, jak np. badania kohortowe lub badania kliniczno-kontrolne (oba typy z grupami kontrolnymi).

\section{WYNIKI}

\section{Epidemiologia}

Skala zjawiska bólów krzyża w populacji dorosłych do dziś, niestety, nie została precyzyjnie określona. Badania epidemiologiczne bólu krzyża wskazują na znaczną niejednorodność ograniczającą możliwość porównywania i gromadzenia danych [2, 5, $17,18,19,20]$. Duże rozbieżności wynikać będą z różnic w definicjach bólu krzyża. Na potrzeby badania przeprowadzonego w Wielkiej Brytanii [21] przyjęto, że ciężki ból przewlekły okolicy lędźwiowo-krzyżowej określono jako ból uniemożliwiający schylanie się (low back pain making it impossible to put on hosiery), co skutkowało 10-krotnym zawężeniem populacji z występującym przewlekłym bólem krzyża.

Według Hoy i wsp. [18] częstość występowania bólu krzyża na całym świecie wynosi 9,4\%, natomiast wg Manchikanti i wsp. [19] to ok. $12 \%$. Szacunkowe roczne występowanie pierwszego epizodu bólu krzyża waha się 6,3-15,4\%, a szacunkowe występowanie każdego epizodu bólu krzyża wynosi 1,5-36\%. Remisja epizodów po 1. roku waha się 54-90\%, jednak większość badań nie wskazuje, czy epizod był ciągły pomiędzy punktem odniesienia a punktem/punktami kontrolnym/ kontrolnymi. Szacunki nawrotów w ciągu 1. roku wahają się $24-80 \%$ [17].

Z danych epidemiologicznych wynika, że 50-80\% [5] populacji ma lub będzie miało w czasie całego życia pojedynczy epizod bólu krzyża i to bez względu na status społeczny. Badania wykazały, że częstość występowania bólu krzyża jest największa w trzeciej dekadzie życia i wzrasta z wiekiem do 60-65 lat, a następnie stopniowo maleje [17]. Znacznie częściej na tę dolegliwość skarżą się kobiety niż mężczyźni $[6,14]$. Niepokojące jest, że w ostatnich latach obserwowana jest rosnąca częstość występowania tej dolegliwości [22]. Warto podkreślić, że również w Polsce, zarówno w przypadku kobiet, jak i mężczyzn, notuje się regularny wzrost liczby chorych hospitalizowanych z powodu bólu (M54 wg klasyfikacji ICD-10), który występuje niezależnie od wieku badanych [23].

\section{Etiologia}

Szacuje się, że tylko 15\% wszystkich bólów krzyża spowodowane jest konkretną chorobą, jak np. stenoza kanału kręgowego, zapalenie kości i szpiku kostnego, choroba Pageta, zespół regresji ogonowej, ogon koński, gruźlica w lokalizacji kręgosłupowej, złamanie, zespół Devica, reumatoidalne zapalenie stawów, artropatia neurogenna i inne, natomiast pozostałe 85\% określa się jako niespecyficzne bóle krzyża [9]. Specyficzne bóle krzyża (objawowe) mają wykrywalną przyczynę w postaci urazu, złamania, infekcji, niezakaźnego zapalenia bądź choroby nowotworowej lub wady rozwojowej [9, 24]. Niespecyficzne bóle krzyża nie mają objawów korzeniowych, zmian w odruchach ani zaburzeń czucia. Mogą być obecne jedynie zmiany zwyrodnieniowe kręgosłupa, ale może też nie być żadnych zmian radiologicznych [24]. Obecność zmian zwyrodnieniowych w kręgosłupie nie tłumaczy wystarczająco patogenezy bólu. Należy brać pod uwagę dodatkowe komponenty patomechanizmu występujące w każdym przypadku, takie jak udział mięśni, nerwów oraz psychiki [25].

W ramach programu National Spine Network, przeprowadzonego w Stanach Zjednoczonych, określono najczęstsze diagnozy wśród pacjentów leczonych z powodu zespołów bólowych kręgosłupa $(n=17774)$ - tabela 1 [26]. Najczęściej postawioną diagnozą była: przepuklina dysku -19,2\%, zespół wąskiego kanału kręgowego - 13,1\% oraz choroba zwyrodnieniowa kręgosłupa -12,9\%.

U większości osób z epizodem ostrego bólu krzyża ból ustępuje w ciągu pierwszych 2 tygodni, a u ok. 80-90\% w ciągu ok. 6 tygodni, niezależnie od rodzaju leczenia, jedynie u 5-10\% pacjentów ból występuje dłużej i przeradza się w ból przewlekły [19]. Choroba ta ma charakter nawrotowy z występującymi naprzemiennie epizodami zaostrzeń i okresami remisji, a każdy rzut bólu krzyża zwiększa ryzyko wystąpienia następnego [17, 27].

Wiele czynników środowiskowych i osobistych wpływa na początek i przebieg bólu krzyża. Często zgłaszane czynniki ryzyka sprzyjające rozwojowi choroby to: zaawansowany/późny wiek, płeć żeńska, czynniki etniczne, czynniki wrodzone, uwarunkowania genetyczne, nieprawidłowa biomechanika stawu, nadwaga, otyłość, palenie tytoniu, wykonywany zawód, podejmowana aktywność fizyczna, duża masa kostna, poziom hormonów, uwarunkowania psychospołeczne, niski poziom wykształcenia, stres, lęk, depresja, niezadowolenie z pracy, brak satysfakcji z wykonywanej pracy, niski poziom wsparcia społecznego w miejscu pracy, złe warunki psychosocjalne [5, 17, 27, 28]. Hampel i Moergel [29] dodatkowo wskazują osobowość człowieka, która wpływa na wszystkie aspekty zachowań powiązanych z bólem oraz na sposób,

TABELA 1. Najczęstsze diagnozy wśród pacjentów leczonych w Stanach Zjednoczonych z powodu dolegliwości bólowych kręgosłupa $(n=17774)$ [26]

\begin{tabular}{|c|c|}
\hline Diagnoza & $\begin{array}{c}\text { Odsetek } \\
\text { pacjentów }\end{array}$ \\
\hline Przepuklina dysku (Herniated disc) & $19,2 \%$ \\
\hline Zespół wąskiego kanału kręgowego (Spinal stenosis) & $13,1 \%$ \\
\hline $\begin{array}{l}\text { Choroba zwyrodnieniowa kręgosłupa } \\
\text { (Degenerative spondylosis) }\end{array}$ & $12,9 \%$ \\
\hline Artropatia międzywyrostkowa (Facet arthropathy) & $9,1 \%$ \\
\hline Syndrom chronicznego bólu (Chronic pain) & $6,1 \%$ \\
\hline Chroniczne zwichnięcie (Chronic sprain/strain) & $4,4 \%$ \\
\hline Skolioza idiopatyczna (Idiopathic scoliosis) & $4,0 \%$ \\
\hline Ostre zwichnięcie (Acute sprain/strain) & $3,5 \%$ \\
\hline Kręgoszczelina (Spondylolysis) & $3,3 \%$ \\
\hline Złamanie pourazowe (Traumatic fracture) & $3,1 \%$ \\
\hline
\end{tabular}


w jaki chory zgłasza ból lekarzowi. Ból krzyża bywa czasem pierwszym objawem depresji maskowanej [25]. Pinheiro i wsp. na podstawie przeprowadzonej metaanalizy wykazali, iż osoby z objawami depresji i zaburzeniami lękowymi mają istotnie podwyższone ryzyko wystąpienia w przyszłości bólu pleców odcinka lędźwiowo-krzyżowego, a ryzyko to dodatnio koreluje z nasileniem objawów depresji u danego pacjenta [30]. Wykazano, że osoby z przewlekłym bólem krzyża są bardziej narażone na występowanie zaburzeń psychicznych w porównaniu z resztą społeczeństwa. Ponadto dane literaturowe wskazują, że negatywne przekonania dotyczące bólu krzyża są powiązane z utrzymującym się wysokim natężeniem bólu w odcinku lędźwiowym kręgosłupa [31]. Pacjenci często unikają wykonywania codziennych czynności, obowiązków zawodowych czy aktywności fizycznej, co daje im poczucie ochrony przed nasileniem bólu [32]. Zjawisko to powoduje znaczne pogorszenie jakości życia, wpływa na zwiększenie niepełnosprawności i wydłużenie absencji w pracy [14].

\section{Postępowanie diagnostyczno-terapeutyczne}

Wytyczne z 2012 r. i związany z nimi systematyczny przegląd autorstwa ICSI [9], dotyczący opieki zdrowotnej dorosłych w ostrym i podostrym bólu krzyża, zalecają w badaniu przedmiotowym i podmiotowym posługiwanie się algorytmem Core Treatment of Non-Specific Low Back Pain Algorithm. Stosuje się go w celu wykluczenia swoistej patologii kręgosłupa i bólu o charakterze korzeniowym, a także w celu oceny pod kątem obecności czynników prognostycznych. Najważniejsza jest wstępna ocena subiektywnego bólu, stan czynnościowy, dobrze przeprowadzony wywiad, obecny stan i historia medyczna pacjenta oraz obecność lub brak „czerwonych flag” (red flags). „Czerwona flaga” to przede wszystkim cechy kliniczne obserwowane w historii medycznej pacjenta lub badaniu fizykalnym, które mogą wskazy wać poważną patologię kręgosłupa i wymagają dalszych badań. „Czerwone flagi” obejmują: objawy ogona końskiego, ryzyko nowotworów złośliwych lub chorobę nowotworową, którą pacjent przeszedł w przeszłości, niewyjaśnioną utratę wagi i gorączkę bez znanej przyczyny, utratę kontroli pęcherza moczowego i jelita grubego, złamania kręgosłupa, promieniujący ból poniżej kolan, brak poprawy bólu krzyża 4-6 tygodni, bardzo silny ból nocny lub ból w spoczynku [9]. Dodatkowo ocena kliniczna powinna obejmować również psychospołeczne czynniki ryzyka, takie jak związek między wysokimi wymaganiami w środowisku pracy, brakiem satysfakcji, stresem a objawami choroby. Grupa międzynarodowych ekspertów skupionych w The Flags Think Tank w 2009 r. opracowała przewodnik w zakresie podkategorii psychospołecznych czynników ryzyka dolegliwości mięśniowo-szkieletowych oraz zaproponowała ich eliminowanie za pomocą identyfikowania „flag” (Flags) [33]. Termin „żółte flagi” (yellow flags) oznacza czynniki indywidualne i został użyty do określenia psychospołecznych czynników prognostycznych dla rozwoju niepełnosprawności po wystąpieniu bólu mięśniowo-szkieletowego. Oczekuje się, że identyfikacja „żółtych flag” we wczesnych badaniach przesiewowych skłania do zastosowania wytycznych interwencyjnych wtórnej profilaktyki. „Niebieskie flagi” (blue flags) są czynnikami ryzyka zachorowania w miejscu pracy, a „czarne flagi” (black flags) są kontekstowymi czynnikami ryzyka, które mogą obejmować problemy społeczne, rodzinne oraz organizacyjne [33].

W diagnostyce niespecyficznego bólu krzyża wg wytycznych ICSI [9] zaleca się u pacjentów w okresie ostrym i podostrym zmniejszenie lub wyeliminowanie wykonywania radiologicznych badań obrazowych (radiogramów przeglądowych, tomografii komputerowej - TK, rezonansu magnetycznego - MR), scyntygrafii kości, SPECT, dyskografii. Obrazowanie powinno być zalecone w przypadku potencjalnych „czerwonych flag”, które wymagają dalszych badań i obejmują ok. 10-15\% całej populacji z bólem krzyża. Większość (85-90\%) to niespecyficzne bóle krzyża. Podobne wskazania zawarto w wytycznych dotyczących rozpoznawania i leczenia bólu krzyża ACP oraz APS [15], w których za celowe uznaje się wykonywanie radiologicznych badań obrazowych jedynie w przypadku pacjentów potencjalnie kwalifikujących się do zabiegów operacyjnych. Badanie diagnostyczne kręgosłupa zaleca się wówczas, gdy ból narasta mimo leczenia i u chorych powyżej 50. r.ż., u których pojawił się po raz pierwszy [18].

W Polsce, zdaniem Domżał [24], nadużywa się badań diagnostycznych, które nagminnie wykonywane są bez uzasadnienia lub pod naciskiem chorego, zwiększając niepotrzebnie koszt leczenia. W postępowaniu diagnostycznym w okresie ostrym w standardach i zaleceniach autorstwa Domżał [24, 25] nie zaleca się wykonywania jakichkolwiek badań diagnostycznych u pacjentów poniżej 50. r.ż., jeśli nie ma objawów neurologicznych ze strony korzeni i wywiad nie wskazuje na złamanie, chorobę nowotworową lub inną, której objawem może być ból krzyża. Należy przyjąć, że jest to nieswoisty ból krzyża. Badania diagnostyczne kręgosłupa zaleca się wówczas, gdy występują objawy neurologiczne albo inne sugerujące złamanie lub chorobę kręgosłupa, a także wtedy, gdy ból narasta mimo leczenia i u chorych powyżej 50. r.ż., u których pojawił się po raz pierwszy.

\section{Wybrane metody leczenia i próba oceny ich skuteczności}

Biorąc pod uwagę dużą częstość występowania bólu krzyża [2, 17, 19, 20] i związane z nim globalne obciążenie dla społeczeństwa [18], konieczne jest powszechne wdrożenie, a także regularne aktualizowanie systemu zasad postępowania diagnostyczno-leczniczego w odniesieniu do zespołów bólowych kręgosłupa. Autorzy wytycznych Polskiego Towarzystwa Fizjoterapii, Polskiego Towarzystwa Medycyny Rodzinnej i Kolegium Lekarzy Rodzinnych w Polsce [34] zwrócili uwagę na potrzebę wprowadzenia systemowych korekt w istniejącym modelu opieki zdrowotnej nad pacjentami z bólami krzyża. Obecnie leczenie w tej grupie osób odbywa się głównie poprzez farmakoterapię i/lub poprzez skierowanie do poradni specjalistycznej. Autorzy dokumentu [34] postulują, żeby w proces świadczonej opieki aktywnie zaangażować lekarzy podstawowej opieki zdrowotnej i fizjoterapeutów. Wybór metody leczenia powinien odbywać się zgodnie z aktualnymi dowodami naukowymi (evidence-based recommendation included - EBR) 
TABELA 2. Metaanaliza porównawcza niefarmakologicznych metod leczenie i profilaktyki bólu krzyża $[9,14,15,34,35]$

\begin{tabular}{|c|c|c|c|c|}
\hline Autor & Typ publikacji & Metoda & Wyniki & Wnioski \\
\hline $\begin{array}{l}\text { Polska } \\
\text { Kassolik } \\
\text { i wsp. } \\
\text { (2017) [34] }\end{array}$ & $\begin{array}{l}\text { Przeglądowa } \\
\text { - zalecenia Pol- } \\
\text { skiego Towarzy- } \\
\text { stwa Fizjoterapii, } \\
\text { Polskiego Towa- } \\
\text { rzystwa Medy- } \\
\text { cyny Rodzinnej } \\
\text { i Kolegium Leka- } \\
\text { rzy Rodzinnych } \\
\text { w Polsce }\end{array}$ & Przegląd literatury & $\begin{array}{l}\text { Przedstawiono założenia nowego podejścia do standardów } \\
\text { postępowania fizjoterapeutycznego u pacjentów z zespoła- } \\
\text { mi bólowymi kręgosłupa szyjnego, piersiowego i lędźwio- } \\
\text { wego. Leczenie fizjoterapeutyczne bólu krzyża powinno } \\
\text { opierać się na prostej ocenie palpacyjnej, na podstawie } \\
\text { której należy ustalić strategię fizjoterapeutyczną w oparciu } \\
\text { o masaż, fizykoterapię (elektroterapia, terapia świattem, } \\
\text { pole magnetyczne, pole elektromagnetyczne), kinezytera- } \\
\text { pię (terapia manualna, użycie trakcji, konkretne ćwiczenia } \\
\text { fizyczne) oraz zaopatrzenie ortopedyczne (niski gorset, } \\
\text { kula inwalidzka). Autorzy proponują zachęcanie pacjenta } \\
\text { do samoleczenia poprzez podanie prostych instrukcji do- } \\
\text { tyczących samodzielnego masażu, autofizykoterapii (kom- } \\
\text { presy ciepłem lub zimnem, stosowanie maści lub środków } \\
\text { przeciwbólowych lub NLPZ, ledoterapia, prądy TENS, sole } \\
\text { do kąpieli, wkładki perłowe lub ozon, korzystanie z sauny } \\
\text { i kąpiele, magnetyczny materac) oraz samodzielnego wyko- } \\
\text { nywania prostych ćwiczeń ruchowych w domu }\end{array}$ & $\begin{array}{l}\text { Proaktywne podejście ma } \\
\text { na celu zwiększenie od- } \\
\text { powiedzialności pacjenta } \\
\text { za leczenie istniejących do- } \\
\text { legliwości i zapobieganie } \\
\text { ich nawrotom. } \\
\text { Szczególny nacisk poło- } \\
\text { żono na fizjoprofilaktykę } \\
\text { w postaci szeroko rozumia- } \\
\text { nej edukacji, dostępności } \\
\text { gotowych rozwiązań i wy- } \\
\text { boru działań fizjoterapeu- } \\
\text { tycznych, które mogą być } \\
\text { wykonywane przez pacjen- } \\
\text { ta w domu }\end{array}$ \\
\hline
\end{tabular}

\begin{tabular}{|c|c|c|c|}
\hline $\begin{array}{l}\text { Wielka } \\
\text { Brytania } \\
\text { de Campos } \\
(2017)[14]\end{array}$ & $\begin{array}{l}\text { Przeglądowa - } \\
\text { wytyczne grupy } \\
\text { ekspertów UK } \\
\text { NICE }\end{array}$ & Przegląd literatury & $\begin{array}{l}\text { Wytyczne podsumowują dowody i zawierają zalecenia doty- } \\
\text { czące trzech obszarów bólu krzyża i rwy kulszowej. Obszary } \\
\text { i leczenia nieinwące oceny } \\
\text { te obejmują: ocenę, leczenie nieinwazyjne i leczenie inwa- } \\
\text { zyjne najbardziej odpowiednie } \\
\text { alternatywną, ocenę ryzyka ocena obrazowająie. Nieinwazyjne } \\
\text { zalecenia terapeutyczne obejmują interwencje niefarmako- } \\
\text { logiczne (w postaci samodzienych ćwiczeń, zaopatrzenia } \\
\text { ortopedycznego, terapii manualnej, akupunktury, elektro- } \\
\text { terapii, terapii psychologicznej, połączonych programów } \\
\text { fizycznych i psychologicznych oraz programy powrotu } \\
\text { do pracy) oraz interwencje farmakologiczne }\end{array}$ \\
\hline
\end{tabular}

USA Przeglądowa -

Chou i wsp. wytyczne ACP

(2017) [35]

\section{Przegląd literatury oparty na metaana- lizach z przeglądów systematycznych i randomizowanych badaniach klinicz- nych}

Przedstawiono aktualne i rozszerzone dowody w stosun- Konieczne są dalsze badaku do wcześniejszego przeglądu ACP/APS [15] dotyczące nia w celu zidentyfikowania niefarmakologicznych terapii leczenia ostrych i przewle- skutecznych niefarmakokłych bólów krzyża. Nowe dowody wskazują, że tai chi (siła logicznych metod leczenia dowodu niska) i redukcja stresu opartego na uważności bólu krzyża

(siła dowodu umiarkowana) są skuteczne w przewlekłym bólu krzyża. Zostały wzmocnione wcześniejsze ustalenia dotyczące skuteczności jogi (siła dowodu umiarkowana). Potwierdzono skuteczność terapii ruchem - kinezyterapii, terapii psychologicznych, rehabilitacji wielodyscyplinarnej, terapii manualnej i masażu dla przewlekłego bólu krzyża (siła dowodów od niskiej do umiarkowanej). Akupunktura jest skuteczna w ostrym bólu krzyża (siła dowodu niska). Istnieje niewiele dowodów na poparcie użycia najbardziej pasywnych terapii fizycznych, takich jak terapia interferencyjna, diatermia krótkofalowa, trakcja, ultrasonografia, taping i elektryczna stymulacja mięśni. Wyjątek stanowiły powierzchowne ciepto i laseroterapia niskiego poziomu

\begin{tabular}{lll}
\hline Goertz & Przeglądowa - & Przegląd systema- \\
i wsp. & wytyczne grupy & tyczny literatury \\
(2012) [9] & medycznej ICSI & oparty wytącznie \\
& & na randomizowa- \\
& & nych badaniach \\
& & \\
& &
\end{tabular}

Od 1993 r. ICSI opracowała ponad 60 wytycznych opartych Dokument jest przeznaczona EBR i dotyczących opieki zdrowotnej dorosłych w ostrym ny przede wszystkim dla oraz podostrym bólu krzyża. Zaproponowano algorytm pracowników służby zdropodstawowego leczenia bólu krzyża (core treatment of wia i innych ekspertów. non-specific low back pain algorithm), algorytm „czerwonej Wytyczne zaprojektowaflagi" (red flags algorithm) oraz algorytm postepowania no, aby pomóc lekarzom w przypadku stwierdzenia bólu korzeniowego (redicular poprzez zapewnienie ram pain algorithm) analitycznych dla oceny i leczenia pacjentów

opartymi na recenzowanych publikacjach naukowych, przeglądach systematycznych, metaanalizach i przeprowadzonych randomizowanych badaniach kontrolnych. Wyniki badań dotyczących niefarmakologicznych metod leczenia i profilaktyki bólu krzyża w Polsce i na świecie zostały przedstawione w tabeli 2. Wynika z nich, że istnieją różnice w proponowanych modelach rehabilitacji bólu krzyża w poszczególnych krajach.
W Polsce wytyczne autorstwa Kassolik i wsp. [34] rekomendują proste strategie terapeutyczne (masaż, fizykoterapia, kinezyterapia, zaopatrzenie ortopedyczne, autoterapia i edukacja).

Autorzy zalecają leczenie fizjoterapeutyczne poprzez m.in. zabiegi elektroterapeutyczne za pomocą prądów TENS, galwanizacji, jonosfery, prądów diadynamik, terapii światłem: lampa Sollux, Bioptron, ledoterapia, laser; termoterapii - okłady 
ciepłem lub zimnem (w zależności od potrzeb) oraz inne, jak: ultradźwięki, magnoterapia, magnetostymulacja. Tymczasem wytyczne ACP [35] i APS [15] wskazują, że istnieje niewiele dowodów na poparcie użycia najbardziej pasywnych terapii fizycznych, takich jak terapia interferencyjna, diatermia krótkofalowa, trakcja, ultrasonografia, taping i elektryczna stymulacja mięśni. Wyjątek stanowią powierzchowne ciepło i laseroterapia niskiego poziomu.

Podobnie sądzą eksperci grupy medycznej ICSI [9], którzy opracowali wytyczne na podstawie systematycznego przeglądu literatury opartego wyłącznie na randomizowanych badaniach klinicznych. Grupa ICSI w pierwszej kolejności w nieswoistym przewlekłym bólu krzyża rekomenduje terapię poznawczo-behawioralną, kinezyterapię prowadzoną pod nadzorem, interwencje oparte na krótkoterminowej edukacji oraz wielodyscyplinarne programy leczenia. Wytyczne nie zalecają stosowania TENS. Nie rekomenduje się również w nieswoistym przewlekłym bólu krzyża akupunktury, podawania kortykosterydów do przestrzeni nadtwardówkowej, iniekcji dostawowych sterydów (do stawów międzywyrostkowych), miejscowych blokad nerwów zaopatrujących stawy międzywyrostkowe, iniekcji w okolicę punktów spustowych, toksyny botulinowej, odnerwienia stawów międzywyrostkowych za pomocą fal radiowych, wewnątrzdyskowych zabiegów z użyciem fal radiowych, wewnątrzdyskowych zabiegów z użyciem energii termicznej, zabiegów uszkadzających zwoje korzeni grzbietowych za pomocą fal radiowych oraz stymulacji rdzenia kręgowego. Nie zaleca się iniekcji wewnątrzdyskowych ani proloterapii [9]. W podstawowym planie leczenia bólu krzyża zaleca się aktywny styl życia oraz ostrożne i odpowiedzialne stosowanie opioidów, niesterydowych leków przeciwzapalnych, przeciwbólowych i przeciwdepresyjnych. Wytyczne ISCI nie zalecają w bólach krzyża terapii zimnem, natomiast rekomendują stosowanie ciepła w złagodzeniu bólu [9].

W 2012 r. ICSI opublikował listę zaleceń opartych na dowodach dotyczących oceny i leczenia ostrych objawów oraz podostrego bólu krzyża. Reprezentatywna grupa międzynarodowych twórców sformułowała jasne, pragmatyczne zalecenia, nadając im jednocześnie siłę rekomendacji w trzech kategoriach: dowody wysokiej jakości, umiarkowana jakość dowodów oraz niska jakość dowodów [9]. Zostały one przedstawione w tabeli 3. Niezwykle istotnym elementem w leczeniu każdego bólu krzyża jest edukacja pacjenta. Najnowsze zalecenia zarówno krajowe [34], jak i światowe [14] przemawiają za skutecznością właściwej edukacji pacjentów w leczeniu bólu krzyża. Edukacja mająca na celu zmianę niewłaściwych nawyków, prowadzenie aktywnego stylu życia i wskazanie prostych wzorów działań, jak posługiwać się własnym kręgosłupem, pozwala zredukować dolegliwości bólowe ze strony kręgosłupa [36]. Edukacja zdrowotna zapewnia dodatkowe korzyści w samodzielnym ćwiczeniu w celu poprawy bólu, niepełnosprawności oraz jakości życia związanej ze zdrowiem psychicznym i fizycznym [37]. Po interwencji edukacyjnej w ramach kampanii zdrowia publicznego w Australii [38], Szkocji [39] i Norwegii [40] zaobserwowano pozytywną zmianę w indywidualnych przekonaniach o bólu krzyża. Ponadto badania

TABELA 3. Lista zaleceń opartych na dowodach dotyczących oceny i leczenia ostrych oraz podostrych objawów bólu krzyża [9]

\section{Dowody o silnej rekomendacji i umiarkowanej jakości dowodów}

\begin{tabular}{l}
\hline Pozostanie aktywnym oraz kontynuowanie codziennych zajęć, łącznie z aktywnością zawodową w granicach dozwolonych przez objawy \\
\hline Leżenie w tóżku jest nieskuteczne i nie powinno być zalecane \\
\hline Edukacja pacjenta np. poradnik na temat aktywności fizycznej/ćwiczeń \\
\hline Ćwiczenia fizyczne zalecane w celu zapobiegania nawrotom bólu krzyża \\
\hline Ćwiczenia fizyczne zalecane w leczeniu podostrego bólu krzyża \\
\hline Ciepło powinno być stosowane w celu złagodzenia bólu \\
\hline Terapia manualna powinna być stosowana we wczesnej interwencji bólu krzyża \\
\hline Lekarze nie powinni rekomendować obrazowania rentgenowskiego oraz tomografii (TK), rezonansu magnetycznego (MR) w niespecyficznym \\
bólu kręgosłupa \\
\hline Obrazowanie powinno być zalecane w celu wykluczenia patologii oraz przy obecności tzw. „czerwonych flag” \\
\hline Dowody o silnej rekomendacji i słabej jakości dowodów
\end{tabular}

Dowody o stabej rekomendacji i umiarkowanej jakości dowodów

Terapia poznawczo-behawioralna

Zewnątrzoponowe iniekcje steroidów mogą być stosowane w krótkotrwałym bólu krzyża

Środki zwiotczające mięśnie mogą być stosowane jako opcja w leczeniu ostrego bólu krzyża, ale możliwe są efekty uboczne

Leki NLPZ* mogą być stosowane krótkoterminowo w łagodzeniu bólu

*NLPZ - niesterydowe leki przeciwzapalne

\begin{tabular}{ll}
\hline \multicolumn{1}{c}{ Dowody o słabej rekomendacji i słabej jakości dowodów } \\
\hline Akupunktura \\
\hline Terapia zimnem \\
\hline Trakcja (wyciąg) \\
\hline
\end{tabular}


kliniczne wykazały, że wprowadzenie broszury informacyjnej zawierającej dokładne informacje na temat bólu krzyża skutecznie zredukowało uporczywy ból pleców [41]. W zależności od potrzeb można również włączyć porady związane $\mathrm{z}$ dostosowaniem stanowiska pracy, wykorzystując do tego celu podstawowe zasady ergonomii [42].

Istotne jest również znaczenie pomocy psychospołecznej jako pozytywnego nastawienia do aktywności fizycznej i profilaktyki przewlekłego bólu krzyża. Wśród osób z zespołami bólowymi kręgosłupa panuje przekonanie, że aktywność fizyczna zwiększy lub pogorszy ból, co powoduje obawy przed ćwiczeniami fizycznymi. Znaczący odsetek chorych ze strachu trwale unika aktywności fizycznej, będąc przekonanym, że spowoduje ona uszkodzenia kręgosłupa i nawrót bólu [9].

Pacjenci, obok unikania aktywności fizycznej (kinezjofobia) [43], również często stronią od wykonywania codziennych czynności i obowiązków zawodowych, co daje im poczucie ochrony przed nasileniem bólu [32]. Tymczasem wyniki badań dowodzą wpływu ćwiczeń fizycznych na skuteczność leczenia i korzystnych efektów leczniczych u chorych z bólami dolnego odcinka kręgosłupa [27, 44, 45, 46]. Istnieją również dowody naukowe na to, że ćwiczenia fizyczne powinny być zalecane w celu zapobiegania nawrotom bólu krzyża [47] Pacjenci, którzy wykazują strach przed aktywnością fizyczną, powinni być informowani o potencjalnej szkodliwości jej braku.

Model rehabilitacji rekomendowany przez ICSI [9] w pierwszej kolejności dotyczy zastosowania kinezyterapii w nieswoistym bólu krzyża [9]. Wszystkie korzystne działania kinezyterapii wynikają z sumowania jej oddziaływania na poszczególne struktury organizmu. Skutkiem tej formy leczenia są: odżywianie chrząstki stawowej, utrzymanie zakresu ruchów w stawach, zachowanie sprawności stawów i tkanek okołostawowych (np. ćwiczenia bierne lub w odciążeniu), zwiększenie siły mięśniowej (ćwiczenia z oporem), likwidacja przykurczów stawowych (mobilizacje ręczne lub wyciągi), odtworzenie prawidłowych stereotypów ruchowych [48]. Ćwiczenia przynoszą również istotne korzyści psychospołeczne, co dotyczy zwłaszcza zajęć grupowych i ćwiczeń w wodzie [49]. Udowodniono skuteczność metody Mechanicznego Diagnozowania i Terapii wg McKenziego (mechanical diagnosis and therapy - MDT) polegającej na diagnozowaniu, leczeniu i profilaktyce zespołów bólowych kręgosłupa i kończyn. Autor metody opracował program postępowania leczniczego, w którym oprócz technik wykonywanych przez terapeutę ważny jest sam ruch pacjenta, ćwiczenia i autoterapia wykonywana w domu. W ćwiczeniach dominują pozycje niskie, głównie leżące. Ruchy czynne powtarzane są wielokrotnie w różnych płaszczyznach, ale w ściśle określonym kierunku, niepowodującym bólu. Dużą wagę przykłada się do zaleceń, które chronią kręgosłup przed kolejnymi urazami i przeciążeniami. Bardzo duży nacisk położony jest na profilaktykę. Programy intensywnych ćwiczeń omawianą metodą przynoszą dobre rezultaty leczenia chorych z ostrymi i przewlekłymi bólami krzyża [50], jak i w bezpośrednim okresie pooperacyjnym $[51,52]$.

\section{Postępowanie terapeutyczne w przewlekłym bólu krzyża}

Zgodnie z wytycznymi ICSI [9] w nieswoistym przewlekłym bólu krzyża nie poleca się leczenia operacyjnego przed ukończeniem 2-letniego okresu nieskutecznego stosowania wszystkich zalecanych metod leczenia zachowawczego. Można rozważać zabieg w przypadkach, gdy programy terapii wielodyscyplinarnej, zawierające połączone programy terapii poznawczo-behawioralnej oraz ćwiczeń fizycznych, są niedostępne, jednak nawet wówczas należy stosować leczenie operacyjne wyłącznie u starannie wybranych pacjentów z maksymalnie długim stopniem choroby bólu krzyża. Dagenasis i wsp. dokonali systematycznego przeglądu literatury [53], w którym ocenili efekty kliniczne i ekonomiczne stosowania różnych metod leczenia przewlekłego bólu krzyża na podstawie kilkunastu badań dotyczących zmian w użyteczności QALY (quality-adjusted life year) stanu pacjentów ( $\mathrm{n}=1725)$ po fizykoterapii, zabiegów zespolenia, zabiegów stabilizacji, ćwiczeń oraz innych metod leczenia przewlekłego bólu kręgosłupa, w tym terapii manualnej SMT (spinal manipulation therapy). QALY to liczba lat życia skorygowana z jego jakością. Metoda ta stanowi jedną z prób analizy użyteczności procedur medycznych w systemie ochrony zdrowia [14]. Średnia wartość wyjściowa użyteczności QALY w badaniach włączonych do przeglądu wyniosła 0,57, wzrastając średnio do 0,67 po okresie badania i zastosowanych procedurach medycznych. Największą zmianę użyteczności zaobserwowano wśród pacjentów poddanych zabiegowi zespolenia $(0,21)$, przy czym byli to jednocześnie pacjenci o najniższej użyteczności wyjściowej $(0,35)$. W następnej kolejności największą zmianę użyteczności uzyskano po interwencji zabiegu stabilizacji $(0,15)$ oraz intensywnej rehabilitacji. Najwyższą końcową wartość użyteczności $(0,68)$ odnotowano u osób poddanych terapii manualnej (SMT) w połączeniu z ćwiczeniami fizycznymi (wzrost o 0,08), przy czym była to grupa o najwyższej wyjściowej wartości użyteczności $(0,6)$.

W świetle powyższych rozważań ukierunkowana aktywność fizyczna i systematycznie wykonywanie ćwiczeń fizycznych jest ważnym elementem profilaktyki pierwotnej i wtórnej ostrego i przewlekłego bólu krzyża. Badania populacyjne wskazują jednak, że jest to najczęściej pomijany element stylu życia współczesnych społeczeństw [54, 55].

\section{WNIOSKI}

Współczesna medycyna ma wciąż duże problemy z diagnostyką i leczeniem bólów krzyża. Niniejsza praca podsumowuje dowody i zawiera zalecenia dotyczące dwóch dużych obszarów bólu krzyża. Obszary te obejmują ocenę i leczenie nieinwazyjne bólu krzyża. Nieinwazyjne zalecenia terapeutyczne dotyczą interwencji niefarmakologicznych, takich jak: ćwiczenia fizyczne, terapie manualne, terapie psychologiczne, rehabilitacja wielodyscyplinarna, manipulacje kręgosłupa, masaż. Aktualne dowody naukowe na temat skuteczności niefarmakologicznych metod leczenia potwierdzone wysokiej jakości badaniami naukowymi sprzyjają rozwojowi i doskonaleniu metod rehabilitacyjnych. Nowe dowody wskazują, że tai chi i redukcja 
stresu opartego na uważności są skuteczne w przewlekłym bólu krzyża i wzmacniają wcześniejsze ustalenia dotyczące skuteczności jogi [35]. Na podstawie dokonanego przeglądu badań $[9,14,15,34,35]$ znaleziono sprzeczne dowody między stosowaniem akupunktury, terapii zimnem, TENS i trakcją kręgosłupa a leczeniem bólu krzyża. Dużą skuteczność w leczeniu dolegliwości bólowych dolnego odcinka kręgosłupa ma kinezyterapia, w tym terapia manualna i aktywne ćwiczenia fizyczne. Niemniej jednak konieczne są dalsze badania w celu zidentyfikowania skutecznych niefarmakologicznych metod leczenia bólu krzyża oraz zrozumienia dodatkowych korzyści wynikających z łączenia poszczególnych interwencji, a także tego, które kombinacje leczenia i sekwencje są najbardziej skuteczne. Programy edukacji zdrowotnej sprzyjają uzyskaniu lepszych efektów w leczeniu bólów krzyża oraz mogą być istotne w zapobieganiu rozwojowi utrzymującego się bólu krzyża o wysokiej intensywności.

\section{PIŚMIENNICTWO}

1. ICD-10 (International Statistical Classification of Diseases and Health Related Problems - Tenth Revision) - Międzynarodowa Statystyczna Klasyfikacja Chorób i Problemów Zdrowotnych - X Rewizja. Genewa: World Health Organization, Centrum Systemów Informacyjnych Ochrony Zdrowia; 2012.

2. Vos T, Flaxman AD, Naghavi M, Lozano R, Michaud C, Ezzati M, et al. Years lived with disability (YLDs) for 1160 sequelae of 289 diseases and injuries 1990-2010: a systematic analysis for the Global Burden of Disease Study 2010. Lancet 2012;380(9859):2163-96. doi: 10.1016/S01406736(12)61729-2.

3. Manek NJ, MacGregor AJ. Epidemiology of back disorders, prevalence, risk factors, and prognosis. Curr Opin Rheumatol 2005;17(2):134-40.

4. Lidgren L. The bone and joint decade 2000-2010. Bull World Health Organ 2003;81(9):629. doi: 10.1590/S0042-96862003000900002.

5. Rubin DI. Epidemiology and risk factors for spine pain. Neurol Clin 2007;25(2):353-71. doi: 10.1016/j.ncl.2007.01.004.

6. Centers for Disease Control and Prevention (CDC). Prevalence and most common causes of disability among adults United States, 2005. MMWR Morb Mortal Wkly Rep 2009;58(16):421-6.

7. Kent PM, Keating JL. The epidemiology of low back pain in primary care. Chiropr Osteopat 2005;13:13-20. doi: 10.1186/1746-1340-13-13.

8. Nowakowski A, Kubaszewski Ł. Zespoły bólowe kręgosłupa. Choroba zwyrodnieniowa kręgosłupa. In: Kruczyński J, Szulc A, editors. Wiktora Degi ortopedia i rehabilitacja. Wybrane zagadnienia z zakresu chorób i urazów narządu ruchu dla studentów i lekarzy. Warszawa: Wydaw. Lekarskie PZWL; 2015. p. 463-8.

9. Goertz M, Thorson D, Bonsell J, Bonte B, Campbell R, Haake B, et al. Adult acute and subacute low back pain. 15th ed. Bloomington (MN): Institute for Clinical Systems Improvement; 2012.

10. Katz JN. Lumbar disc disorders and low-back pain: socioeconomic factors and consequences. J Bone Joint Surg Am 2006;88(Suppl 2):21-4. doi: 10.2106/JBJS.E.01273.

11. Dagenais S, Caro J, Haldeman S. A systematic review of low back pain cost of illness studies in the United States and internationally. Spine J 2008;8(1):8-20. doi: 10.1016/j.spinee.2007.10.005.

12. Luo X, Pietrobon R, Sun SX, Liu GG, Hey L. Estimates and patterns of direct health care expenditures among individuals with back pain in the United States. Spine 2004;29(1):79-86. doi: 10.1097/01.BRS.0000105527.13866.0F.

13. Korabiusz K, Lubkowska A, Wawryków A. Przegląd najczęściej stosowanych metod fizjoterapii w zespołach bólowych kręgosłupa wśród pacjentów NZOZ ŚROD-MED w Policach. J Educ Health Sport 2016;6(4):127-40. doi: 10.5281/zenodo.49894.

14. de Campos TF. Low back pain and sciatica in over 16s: assessment and management NICE Guideline [NG59]. J Physiother 2017;63(2):120. doi: 10.1016/j.jphys.2017.02.012.
15. Chou R, Qaseem A, Snow V, Casey D, Cross JT Jr, Shekelle P, et al. Diagnosis and treatment of low back: a joint clinical practice guideline from the American College of Physicians and the American Pain Society. Ann Intern Med 2007;147:478-91.

16. Guyatt GH, Oxman AD, Vist GE, Kunz R, Falck-Ytter Y, Alonso-Coello P, et al. GRADE: an emerging consensus on rating quality of evidence and strength of recommendation. BMJ 2008;336(7650):924-6. doi: 10.1136/ bmj.39489.470347.AD.

17. Hoy D, Brooks P, Blyth F, Buchbinder R. The Epidemiology of low back pain. Best Pract Res Clin Rheumatol 2010;24(6):769-81. doi: 10.1016/j. berh.2010.10.002.

18. Hoy D, March L, Brooks P, Blyth F, Woolf A, Bain C, et al. The global burden of low back pain: estimates from the Global Burden of Disease 2010 study. Ann Rheum Dis 2014;73(6):968-74. doi: 10.1136/annrheumdis-2013-204428.

19. Manchikanti L, Singh V, Falco FJ, Benyamin RM, Hirsch JA. Epidemiology of low back pain in adults. Neuromodulation 2014;17(Suppl 2):3-10. doi: 10.1111/ner.12018.

20. Yiengprugsawan V, Hoy D, Buchbinder R, Bain C, Seubsman SA, Sleigh AC. Low back pain and limitations of daily living in Asia: longitudinal findings in the Thai cohort study. BMC Musculoskelet Disord 2017;18(1):19. doi: 10.1186/s12891-016-1380-5.

21. Palmer KT, Walsh K, Bendall H, Cooper C, Coggon D. Back pain in Britain: comparison of two prevalence surveys at an interval of 10 years. BMJ 2000;320(7249):1577-8.

22. Freburger JK, Holmes GM, Agans RP, Jackman AM, Darter JD, Wallace AS, et al. The rising prevalence of chronic low back pain. Arch Intern Med 2009;169(3):251-8. doi: 10.1001/archinternmed.2008.543.

23. Michalik R, Kowalska M, Kotyla P, Owczarek AJ. Częstość hospitalizacji pacjentów z bólami krzyża w Polsce na tle krajów europejskich. Pomeranian J Life Sci 2015;61(2):214-9. doi: 10.21164/pomjlifesci.81.

24. Domżał TM. Neurologiczne postępowanie w bólach krzyża - standardy i zalecenia. Pol Prz Neurol 2010;6(2):59-9.

25. Domżał TM. Przewlekłe nieswoiste bóle krzyża - stara dolegliwość czy nowa choroba neurologiczna? Pol Prz Neurol 2007;3(4):216-27.

26. Fanuele JC, Birkmeyer NJ, Abdu WA, Tosteson TD, Weinstein JN. The impact of spinal problems on the health status of patients: have we underestimated the effect? Spine 2000;25(12):1509-14.

27. Hayden JA, Dunn KM, van der Windt DA, Shaw WS. What is the prognosis of back pain? Best Pract Res Clin Rheumatol 2010;24(2):167-79. doi: 10.1016/j.berh.2009.12.005.

28. da Costa BR, Vieira ER. Risk factors for work-related musculoskeletal disorders: a systematic review of recent longitudinal studies. Am J Ind Med 2010;53(3):285-323. doi: 10.1002/ajim.20750.

29. Hampel P, Moergel MF. Staging of pain in patients with chronic low back pain in inpatient rehabilitation: validity of the Mainz Pain Staging System of pain chronification. Schmerz 2009;23(2):154-65. doi: 10.1007/ s00482-008-0743-8.

30. Pinheiro MB, Ferreira ML, Refshauge K, Ordoñana JR, Machado GC, Prado LR, et al. Symptoms of depression and risk of new episodes of low back pain: a systematic review and meta-analysis. Arthritis Care Res (Hoboken) 2015;67(11):1591-603. doi: 10.1002/acr.22619.

31. Ng SK, Cicuttini FM, Wang Y, Wluka AE, Fitzgibbon B, Urquhart DM. Negative beliefs about low back pain are associated with persistent high intensity low back pain. Psychol Health Med 2017;22(7):790-9. doi: 10.1080/13548506.2016.1220602.

32. Wong WS, Chen PP, Yap J, Mak KH, Tam BK, Fielding R. Chronic pain and psychiatric morbidity: a comparison between patients attending specialist orthopedics clinic and multidisciplinary pain clinic. Pain Med 2011;12:246-59. doi: 10.1111/j.1526-4637.2010.01044.x.

33. Kendall NA, Burton AK, Main CJ, Watson P. Tackling musculoskeletal problems: a guide for clinic and workplace identifying obstacles using the psychosocial flags framework. London: The Stationery Office; 2009.

34. Kassolik K, Rajkowska-Labon E, Tomasik T, Pisula-Lewadowska A, Gieremek K, Andrzejewski W, et al. Recommendations of the Polish Society of Physiotherapy, the Polish Society of Family Medicine and the College of Family Physicians in Poland in the field of physiotherapy of back pain syndromes in primary health care. Fam Med Primary Care Rev 2017;19(3):32334. doi: 10.5114/fmpcr.2017.69299.

35. Chou R, Deyo R, Friedly J, Skelly A, Hashimoto R, Weimer M. Nonpharmacologic therapies for low back pain: a systematic review for an 
American College of Physicians Clinical Practice Guideline. Ann Intern Med 2017;166(7):493-505. doi: 10.7326/M16-2459.

36. Engers A, Jellema P, Wensing M, van der Windt DA, Grol R, van Tudler MW Individual patient education for low back pain. Cochrane Database Syst Rev 2008;(1):CD004057. doi: 10.1002/14651858.CD004057.pub3.

37. Zhang $Y$, Wan $L$, Wang $X$. The effect of health education in patients with chronic low back pain. J Int Med Res 2014;42(3):815-20. doi: 10.1177/0300060514527059.

38. Buchbinder R, Jolley D, Wyatt M. Population based intervention to change back pain beliefs and disability: three part evaluation. BM] 2001;322(7301):1516-20. doi:10.1136/bmj.322.7301.1516.

39. Waddell G, O'Connor M, Boorman S, Torsney B. Working Backs Scotland: a public and professional health education campaign for back pain. Spine 2007;32(19):2139-43. doi:10.1097/brs.0b013e31814541bc.

40. Werner EL, Ihlebaek C, Laerum E, Wormgoor ME, Indahl A. Low back pain media campaign: no effect on sickness behaviour. Patient Educ Couns 2008;71:198-203. doi:10.1016/j.pec.2007.12.009.

41. Coudeyre E, Tubach F, Rannou F, Baron G, Coriat F, Brin S, et al. Effect of a simple information booklet on pain persistence after an acute episode of low back pain: a non-randomized trial in a primary care setting. PLoS One 2007;2(8):e706. doi: 10.1371/journal.pone.0000706.

42. Lubkowska W. The potential of computer software that supports the diagnosis of workplace ergonomics in shaping health awareness. AIP Conference Proceedings 2017;1906(1):180008-1-180008-3. doi: $10.1063 / 1.5012461$

43. Picavest HS, Vlaeyen JW, Schouten JS. Pain catastrophizing and kinesiophobia: predictors of chronic low back pain. Am J Epidemiol 2002;156(11):1028-34.

44. Kool J, Bachmann S, Oesch P, Knuesel O, Ambergen T, de Bie R, et al. Function-centered rehabilitation increases work days in patients with nonacute nonspecific low back pain: 1-year results from a randomized controlled trial. Arch Phys Med Rehabil 2007;88(9):1089-94. doi: 10.1016/j.apmr.2007.05.022.

45. Schaafsma F, Schonstein E, Whelan KM, Ulvestad E, Kenny DT, Verbeek JH. Physical conditioning programs for improving work outcomes in workers with back pain. Cochrane Database Syst Rev 2010;(1):CD001822. doi: 10.1002/14651858.CD001822.pub2.

46. Wright A, Lloyd-Davies A, Williams S, Ellis R, Strike P. Individual active treatment combined with group exercise for acute and subacute low back pain. Spine 2005;30(11):1235-41.

47. Choi BK, Verbeek JH, Tam WW, Jiang JY. Exercises for prevention of recurrences of low-back pain. Occup Environ Med 2010;67(11):795-6. doi: 10.1136/oem.2010.059873.

48. Księżopolska-Orłowska K. Rehabilitation procedures in rheumatology. Reumatologia 2012;50(2):181-4.

49. Łubkowska W, Zdeb T, Mroczek B. Assessment of physiological spine curvature in girls who trained competitive swimming versus non-swimming girls. Fam Med Primary Care Rev 2015;17(3):189-92. doi: 10.5114/ fmpcr/58738.

50. Rąpała A, Rąpała K, Lackowicz W, Łukawski S. Ocena kliniczna metody McKenzie w chorobie dyskowej w materiale Kliniki Ortopedii CMKP w Otwocku. Ortop Traumatol Rehabil 2004;6(2):183-9.

51. Ostelo RW, de Vet HC, Waddell G, Kerckhoffs MR, Leffers P, van Tulder M. Rehabilitation following first-time lumbar disc surgery: a systematic review within the framework of the cochrane collaboration. Spine 2003;28(3):209-18.

52. Friedrich M, Gittler G, Arendasy M, Friedrich KM. Long-term effect of a combined exercise and motivational program on the level of disability of patients with chronic low back pain. Spine 2005;1(30):995-1000.

53. Dagenais S, Caro J, Haldeman S. A systematic review of low back pain cost of illness studies in the United States and internationally. Spine J 2008;8(1):8-20. doi: 10.1016/j.spinee.2007.10.005.

54. Bendíková E, Dobay B. Physical and sport education as a tool for development of a positive attitude toward health and physical activity in adulthood. Eur J Contemp Educ 2017;6(1):14-21. doi: 10.13187/ejced. 2017.1.144.

55. Nowak MA. Physical activity and its associations with other lifestyle elements in polish women. J Hum Kinet 2011;29:161-72. doi: 10.2478/ v10078-011-0050-9. 